\title{
PERCEIVED CAREER-RELATED PRACTICES AND KNOWLEDGE SHARING BEHAVIOUR: A PRELIMINARY STUDY IN OMAN
}

\section{Faridahwati Mohd. Shamsudin ${ }^{1 *}$, Said Hamdan Al-Badi ${ }^{2}$, Alexander Bachkirov ${ }^{3}$ and Ahmad Said Alshuaibi ${ }^{4}$}

\author{
${ }^{1}$ Othman Yeop Abdullah Graduate School of Business, Universiti Utara Malaysia, \\ 06010 Sintok, Kedah, Malaysia \\ ${ }^{2,3}$ College of Economics and Political Science, Sultan Qaboos University, Oman \\ ${ }^{4}$ School of Business, Universiti Utara Malaysia, 06010 Sintok, Kedah, Malaysia
}

$$
\text { *Corresponding author: faridah@uum.edu.my }
$$

Published online: 30 December 2016

To cite this article: Mohd Shamsudin, F., Al-Badi, S.H., Bachkirov, A., and Alshuaibi, A.S. (2016). Perceived career-related practices and knowledge sharing behaviour: A preliminary study in Oman. Asian Academy of Management Journal, 21(Supp. 1), 25-47. http://dx.doi.org/10.21315/aamj2016.21.supp.1.2

To link to this article: http://dx.doi.org/10.21315/aamj2016.21.supp.1.2

\begin{abstract}
We examine the relationship between career-related practices and knowledge sharing behaviour in Oman. The practices considered in this study are perceived security, employability, and promotion opportunities. Although studies on knowledge sharing behaviour at work are plentiful, limited empirical evidence exists of the role of careerrelated practices in this regard. Hence, in fulfilling this gap, a survey was conducted among 129 employees at both managerial and professional levels across various industries in Muscat, Oman. Using multiple regression analysis, the results showed that all practices significantly predicted the dimension of knowledge collecting behaviour, but not knowledge donating behaviour. The implications of the findings on the importance of putting in place practices to support and develop one's career are discussed as a way to promote knowledge collecting in the organisation.
\end{abstract}

Keywords: employability, job security, knowledge sharing, Oman, promotion opportunity 


\section{INTRODUCTION}

Knowledge is recognised as an important organisational asset and resource because it helps the organisation to develop its competitive advantage especially in a dynamic environment (Cabrera, Collins, \& Salgado, 2006). Toward that end, the organisation has to exploit such resource to its advantage. One way how this can be done is by encouraging employees to share their knowledge with each other members in the organisation (Cabrera et al., 2006). Here, knowledge refers to both the explicit and tacit knowledge that the individuals possess (Wyatt, 2001). Of the two, organisations have a bigger challenge in harnessing the tacit knowledge to their advantage because such "disappears" the moment the "owners" leave the organisation, and more importantly, when the owners of the knowledge are part of the core employees (Hall \& Moss, 1998; Chiang, Han, \& Chuang, 2011; Willman, O'Creevy, Nicholson, \& Soane, 2001).

Studies on knowledge sharing behaviour are increasing in number over the years, reflecting the importance of knowledge acquisition, transfer and application in the organisation. One of the research streams pertains to investigating the factors that promote (or inhibit) knowledge sharing behaviour at work. Although personal factors, such as personality variables have been found to be significantly associated with knowledge sharing behaviour (Matzler, Renzl, Müller, Herting, \& Mooradian, 2008; Matzler, Renzl, Mooradian, von Krogh, \& Mueller, 2011; Mooradian, Renzl, \& Matzler, 2006), we are more interested in investigating organisational factors. Because knowledge sharing and knowledge transfer are important in helping the organisation develop its competitive advantage, the organisation has to provide a conducive work environment to encourage employees at all levels to share and transfer their knowledge. Consistently, according to Robbins, Judge, Millett, and Boyle (2013), a good working environment has a significant bearing on individual behaviour at work. In line with this argument, researchers have considered organisation factors, such as rewards/incentives system (Bartol \& Srivastava, 2002; Cabrera et al., 2006; Kulkarni, Ravindran, \& Freeze, 2006; Yao, Kam, \& Chan, 2007), and organisational culture/climate (Ismail Al-Alawi, Yousif Al-Marzooqi, \& Fraidoon Mohammed, 2007; Bock, Zmud, Kim, \& Lee, 2005).

One important organisational factor that has not been considered in past literature is related to career development practices. Even though previous works have shown that high-commitment HRM practices, such as employment practices, appraisal, competitiveness, fair compensation, and comprehensive training and development enhance individual knowledge-sharing behaviour (Chiang et al., 2011; Fong, Ooi, Tan, Lee, \& Chong, 2011), specific career-related practices are yet to be investigated. We contend that career development practices, such as the 
provision of job security, promotion opportunities, and employability are likely to promote knowledge sharing behaviour in the organisation because they are signals of management support toward personal career growth and development (Foong-Ming, 2008). The argument is consistent with Social Exchange Theory (SET) Blau, (1964) that postulates that individuals assess the benefits and costs in deciding whether or not to pursue their relationship or exchange with others. Implicit in this definition is that the relationship or exchange is governed by the norm of reciprocity (Gouldner, 1960) whereby people should return the benefits given to them in a relationship. In the employment context, when employees perceive that the management has given them the necessary support, the former is likely reciprocate by demonstrating positive behaviour, such as knowledge sharing. Studies indicate that when the organisation is perceived to have provided the necessary support for personal career development, employees are likely to have a lower turnover intention (Foong-Ming, 2008) and be more satisfied in their job (Chen, Chang, \& Yeh, 2004; Kim, 2002). Hence, given the gap in the existing literature and in response to the recommendation made by Wang and Noe (2010), who suggest that more research should be conducted in examining the organisational context purported to such behaviour, we attempt to investigate the role of career-related practices in knowledge sharing behaviour.

Secondly, our study adds to the literature in knowledge sharing in a different cultural context. We chose Oman in particular for several reasons. Most studies on knowledge sharing have been carried out mainly in the West (e.g., Auh \& Menguc, 2013; Cabrera et al., 2006; Van den Hoof \& Van Weenen, 2004). Increasingly, more studies have been conducted in the East such as China (Ardichvili, Page, \& Wentling, 2003), Taiwan (Wang \& Houe, 2015; Wu, 2013), Singapore (Jer Yuen \& Shaheen Majid, 2007), Malaysia (Fong et al., 2011), and South Korea (Bock et al., 2005). Studies in the Middle Eastern region, in particular, are scarce. Given the vibrant and dynamic environment of this region, particularly the Gulf Countries of Saudi Arabia, Bahrain, Kuwait, Qatar, UAE, and Oman, and the increasing role it plays at the world stage economically, socially, and politically, it is unfortunate that studies of this sort are scarce. We argue that examining knowledge sharing behaviour is more critical in this part of the region. The Gulf hosts a substantial number of guest workers (i.e. expatriate workers or foreign workers), who primarily work on a contractual basis. Among them, retaining skilled and professional employees is one of the biggest challenges facing many organisations (Iqbal, 2010; "UAE firms grapple with," 2008). Also, due to localisation policies, local nationals tend to job hop, looking for better career opportunities (Maceda, 2014). In this situation, organisations are at risk of losing the knowledge, especially the implicit knowledge the employees have when they decide to leave or are forced to leave. In this employment context, we are interested in understanding how knowledge 
sharing is affected. In this present work, we are concerned with examining the phenomenon of knowledge sharing behaviour at the individual level because knowledge essentially rests with the individual and it is the collective knowledge that influences team and organisational effectiveness (Cabrera \& Cabrera, 2005; Wang \& Noe, 2010).

Toward meeting our research objective, we organise this paper as follows. Next, we discuss the relevant literature on knowledge sharing is presented, leading towards the development of the research hypotheses. Then, we proceed by explaining how the present study was conducted and data analysed. Results of the analyses are presented next, followed by a discussion on the findings. Some concluding remarks, limitations of the present research, and implications of the findings to practice and future research are offered next.

\section{LITERATURE REVIEW}

\section{Knowledge Sharing Behaviour}

Although there is no consensus among scholars on what constitutes knowledge and how it is different from information, we agree with researchers who contend that distinguishing the two terms in knowledge sharing research lacks practical significance (Bartol \& Srivastava, 2002). In this context, we adopt the perspective of Wang and Noe (2010), who assert that knowledge is information processed by individuals relevant for individual, team, and organisational effectiveness. However, the organisation has to effectively exploit such processed information or knowledge for its benefit. Here, encouraging employees, especially the experts to share their knowledge with others in the organisation becomes crucial (Wang \& Noe, 2010). De Vries, Van den Hooff, and De Ridder (2006) define knowledge sharing as the process where individuals mutually exchange their tacit and explicit knowledge thereby jointly creating new knowledge. Because knowledge sharing involves, at least, two individuals, it suggests that in this process one individual acts as the supplier of knowledge and the other as the recipient of knowledge (Ardichvili et al., 2003). But, these roles are not static as they can move back and forth during the exchange. Following De Vries et al. (2006), we identify two central behaviours of knowledge sharing: knowledge donating and knowledge collecting. While knowledge donating involves communicating one's personal intellectual capital to others, knowledge collecting refers to consulting others to get them to share their intellectual capital. A personal who donates (or brings) knowledge acts as a knowledge supplier, while a person who collects (or gets) knowledge is referred to as a knowledge recipient (De Vries et al., 2006). 


\section{Perceived Career-related Practices and Knowledge Sharing Behaviour}

We define career related practices as practices implemented by the organisation to help employees plan and develop their long-term career. These practices represent high-commitment HRM practices (Foong-Ming, 2008), which are generally defined as practices that are put in place to induce high commitment and motivation from employees (Chiang et al., 2011; Whitener, 2001). An organisation that takes its responsibility seriously for its employees will provide the necessary support and resources to enable them to grow and develop their career. When the organisation is perceived to be doing that, the employees are likely to develop a sense of commitment and are likely to be motivated in their job. Previous works have shown that high-commitment HRM practices, such as employment practices, appraisal, competitiveness, fair compensation, and comprehensive training and development enhance individual knowledge-sharing behaviour (Chiang et al., 2011; Fong et al., 2011). Using social exchange theory as their foundation, Chiang et al. (2011) argue that such practices were perceived to be a significant organisational support, which forms the basis for employees to reciprocate the contribution made the organisation by engaging in knowledge sharing behaviour.

Three career-related practices are examined in the present study. They are job security, promotional opportunities, and employability. We choose these practices because we believe that they represent the important components of how an organisation should develop the careers of the employees (Eby, Allen, \& Brinley, 2005). For instance, if the employees wish to develop a long-term career with the organisation, job security is pre-requisite.

\section{Perceived Job Security}

According to Maslow's (1943) hierarchy of needs, within the employment context, job security represents the need for security. Job security can be understood as "a psychological state in which workers vary in their expectations of future job continuity within an organisation" (Kraimer, Wayne, Liden, \& Sparrowe, 2005, p. 390). Because job security denotes job stability, it has been found to be associated with positive work outcomes such as organisational commitment (De Witte \& Näswall, 2003). Also, when individuals perceive that their job is insecure, their health and well-being will be negatively affected (De Cuyper, Baillien, \& De Witte, 2009; Silla, Gracia, \& Peiro, 2005). In their meta-analytic study on job insecurity and its consequences, Sverke, Hellgren, and Naswall (2002) found the negative effect of job insecurity on job satisfaction, trust, and performance. 
Although studies on job security and knowledge sharing behaviour are nonexistent, we postulate that when individuals perceive their job to be stable and secure, they will likely to share their tacit and explicit knowledge with their peers and other individuals in the organisation. Providing job security is a form of organisational support (Laschinger, Purdy, Cho, \& Almost, 2006). According to the norms of reciprocity and social exchange theory (Blau, 1964), when the employees perceive that the organisation has shown the necessary support, they are likely to return such favor by engaging in positive behaviours. Studies have shown that perceived organisational support enhances pro-social behaviours such as helping behaviours (De Cuyper, Schreurs, Elst, Baillien, \& De Witte, 2014). Indeed, knowledge sharing behaviour is generally assumed to share similarities with prosocial behaviours (Gagné, 2009). Hence, we conjectured that:

H1: Perceived job security is positively related to knowledge sharing behaviour.

\section{Perceived Promotional Opportunities}

Advancing through the hierarchical ladder within the organisation is typically how individuals develop their career (Dessler, 1991). When an employee is promoted, it shows that he or she has performed as expected. As part of the internal career development program, the organisation should clearly communicate to the employees the policies and procedures regarding internal promotion. In this way, they are likely to perceive that they have the opportunity to be promoted when and if they have met the relevant job requirements. As promotion normally involves the assessment of necessary skills and abilities, an organisation that provides training for skill and knowledge enhancement is likely to be perceived as giving the necessary support (Wickramasinghe, 2010). In other words, giving an opportunity for internal promotion can be perceived as a way the organisation values its employees (Foong-Ming, 2008).

Although previous work is limited, the existing empirical evidence indicates that promotional or career advancement opportunities are related to various workrelated attitudes and behaviours, such as job satisfaction (Ellickson, 2002), turnover intentions (Stahl, Chua, Acliguiri, Cerdin, \& Taniguchi, 2009), and job stress (Wickramasinghe, 2010; Yang, Che, \& Spector, 2008). Further, consistent with social exchange theory and the norm of reciprocity, we speculate that promotional opportunities will enhance knowledge sharing behaviour because by doing so the employees can return the "favor" to the organisation. 
A promotion typically comes with a rise in pay, greater work challenges and responsibilities, higher status and more autonomy (Foong-Ming, 2008), which are likely to motivate the employee to demonstrate better job performance in the future. According to expectancy theory, when individuals are able to connect between effort, performance, and reward, they will be motivated to perform well (e.g., share knowledge), especially when the reward is perceived to be valuable (Lawler \& Suttle, 1973). Understanding that promotion can be instrumental toward organisational effectiveness, it is imperative that the employees are given the opportunity to enhance their career through internal promotion. Thus, we hypothesised the following:

H2: Perceived promotional opportunities in the organisation are positively associated with knowledge sharing behaviour.

\section{Perceived Employability}

Because organisations have to operate in a turbulent and dynamic environment that forces them to rapidly respond to changes, delayering, restructuring and flattening of the organisations have become the strategic options (Chay \& Aryee, 1999). The way the organisations do their business has undoubtedly changed the employment relationship. Many organisations are no longer able to provide a lifetime employment to employees (Hall \& Moss, 1999; Matanle, 2006), prompting them to self-manage their careers (Briscoe \& Hall, 2006; Sturges, Guest, Conway, $\&$ Mackenzie Davey, 2002). Indeed, career self-management has now taken the center stage within the debates of career planning where the individuals play a much bigger role in developing and managing their career (Chay \& Aryee, 1999). However, even though employees may now have to rely on themselves to develop their careers (Chay \& Aryee, 1999), the organisation still has the responsibility to provide the necessary support for the employees to personally growth and develop (Yousaf \& Sanders, 2012), either inside or outside the organisation (Briscoe \& Hall, 2006; Sturges et al., 2002). Helping the employees to become employable by providing the necessary resources and opportunities is one way the organisation can facilitate their career development (Hall \& Moss, 1998; Yousaf \& Sanders, 2012).

Employability can be defined as the workers' perceptions about available job opportunities inside or outside the organisation (Berntson \& Marklund, 2007; De Cuyper et al., 2014). Yousaf and Sanders (2012) note that companies offer employability practices such as systematic competency development, personal career plans, and on-the-job training are offered as ways to improve a person's attractiveness to the inside and outside labor market when needed. These practices 
enable employees to acquire portable and marketable skills (Hall \& Moss, 1998), which will enable them to be more employable.

We speculate that employees who perceive that they are employable are likely to share their resources and knowledge with their peers and other individuals as a way to reciprocate to the provision of the necessary support given by their organisation. By sharing their knowledge with other people, they are helping the organisation to perform better. Being employable then serves as an incentive to return the "favor" given by the organisation by engaging in positive behaviours. Indeed, perceived employability was found to reduce workplace bullying (De Cuyper et al., 2009), which is a negative work outcome frowned upon by organisations (Zapf \& Einarsen, 2001). In their study on 230 academic staff at a public university in Pakistan, Yousaf and Sanders (2012) found a positive relationship between employability and affective organisational commitment. They discussed their finding in terms of the norm of reciprocity, noting that the positive perceptions of employability arouse individuals' emotional attachment with the organisation as a reciprocation of what they receive. Various studies have found that positive work attitudes like organisational commitment lead to positive behavioural outcomes such as helping behaviour (Deckop, Cirka, \& Andersson, 2003), which is a dimension of organisational citizenship behaviour (Schappe, 1998).

Based on the arguments above, we hypothesised the following:

H3: Employability is positively associated with knowledge sharing behaviour.

\section{METHOD}

\section{Research Context}

The Sultanate of Oman is one of the countries in the Middle East that make up the Gulf Cooperation Council (GCC) along with Qatar, Saudi Arabia, Kuwait, United Arab Emirates, and Bahrain. The modern history of the Sultanate of Oman started with the ascension of Sultan Qaboos bin Said Al Said to the throne in 1970, taking over the helm from his father. Charismatic and visionary, rapid economic development soon followed after the exploitation of the country's primary resources of oil and gas in 1973. However, lack of skilled local workforce meant that the country had to import foreign laborers. Citing job market statistics in Oman, De Bel-Air (2015) reported that foreign nationals made up 26.5 percent of the total population in 1993, 23.9 percent in 2003, and 36 percent in 2009 when the global financial crisis occurred. 
Unemployment among its nationals, reaching approximately 15 percent in total and close to 30 percent among the youth group, has prompted the Omani government to re-assess its policy on foreign workforce (De Bel-Air, 2015). The Omanization policy, put in place in 1988, aims to reduce the dependency on foreign workforce and expand the proportion of Omanis in the labor force (De Bel-Air, 2015). It is the dynamic feature of the job market in Oman where guest workers and the nationals are in constant and active contact with each other that has motivated us to explore the issue of knowledge sharing behaviour in the country. Secondly, we chose Oman due to practicality purposes.

\section{Sample and Data Collection Procedure}

We conducted a survey among 129 participants who had managerial and professional/technical jobs across diverse organisations in Muscat, Oman. We chose this group of participants because they possess the core knowledge related to the organisational operations. Furthermore, the organisation will lose the invaluable resource if they leave the organisation. This is because they will take with them both the explicit and, more importantly, the tacit knowledge (Chiang et al., 2011; Willman et al., 2001) when they leave. Because we assume that knowledge sharing behaviour is an individual activity, the unit of analysis was individual.

To help with data collection, we recruited some undergraduate students. They were carefully trained to handle the survey. For instance, they were clearly told who should be eligible to participate, how the survey should be administered, etc. To ensure the validity of the participants, we required that our recruiters returned the complete survey along with each participant's business card. We then randomly called some of the participants to verify their participation. The issue of anonymity and confidentiality did not arise because we did not use the business card to identify the participants, but merely as a control tool. While such method of data collection may open to potential systemic bias, our dataset indicated that the participants somewhat mirrored our population of nationals and guest workers (skilled and professional) (De Bel-Air, 2015; International Labor Organization (ILO), 2010).

Before the survey was administered, the questions were validated by a senior faculty member at the university where the authors are attached to. It was also pretested to a number of employees for any ambiguity. Their feedback was later incorporated into the final survey. To encourage the participants to complete the survey, an introduction letter detailing the purpose, importance, confidentiality and anonymity, and voluntariness was prepared. 
Faridahwati Mohd. Shamsudin et al.

Table 1

Profile of the Participants

\begin{tabular}{|c|c|c|}
\hline Items & Frequency & $\%$ \\
\hline \multicolumn{3}{|l|}{ Gender } \\
\hline - Male & 77 & 59.7 \\
\hline - Female & 52 & 40.3 \\
\hline \multicolumn{3}{|l|}{ Status } \\
\hline - Married & 85 & 65.9 \\
\hline - Single & 42 & 32.6 \\
\hline - Divorced $\mid$ widowed & 2 & 1.6 \\
\hline \multicolumn{3}{|l|}{ Education } \\
\hline - Others & 3 & 2.3 \\
\hline - Diploma $\backslash T e c h n i c a l$ certificate & 19 & 14.7 \\
\hline - $\mathrm{BA} / \mathrm{BSc}$ & 60 & 46.5 \\
\hline - MA/MBA & 36 & 27.9 \\
\hline - $\mathrm{PhD} / \mathrm{DBA}$ & 11 & 8.5 \\
\hline \multicolumn{3}{|l|}{ Religion } \\
\hline - Islam & 102 & 79.1 \\
\hline - Christianity & 14 & 10.0 \\
\hline - Hinduism & 9 & 7 \\
\hline - Others & 2 & 1.6 \\
\hline \multicolumn{3}{|l|}{ Job type } \\
\hline Managerial & 65 & 50.8 \\
\hline Professional & 63 & 49.2 \\
\hline \multicolumn{3}{|l|}{ Industry } \\
\hline - Oil and gas & 19 & 14.7 \\
\hline - Health care & 5 & 3.9 \\
\hline - Banking \finance & 23 & 17.8 \\
\hline - Telecommunication & 5 & 3.9 \\
\hline - Education & 48 & 37.2 \\
\hline - Aviation & 1 & 0.8 \\
\hline - Others & 23 & 17.8 \\
\hline \multicolumn{3}{|l|}{ Work sector } \\
\hline - Private & 89 & 69 \\
\hline - Public & 40 & 31 \\
\hline \multicolumn{3}{|l|}{ Nationality } \\
\hline - Omani & 81 & 62.8 \\
\hline - Non-Omani & 45 & 34.9 \\
\hline \multicolumn{3}{|l|}{ Type of organization } \\
\hline - Local Omani company & 109 & 84.5 \\
\hline - Foreign company & 20 & 15.5 \\
\hline Age & Mean & ears \\
\hline Tenure & Mean & ears \\
\hline
\end{tabular}


Table 1 shows the profile of the participants. As shown by the table, slightly more than half of the participants were male (59.7\%). The majority were married (65.9\%), had university degrees (82.9\%), Muslims (79.1\%), worked with private companies $(69.0 \%)$, were Omanis $(62.8 \%)$, and were attached to local Omani organisations $(84.5 \%)$. Half of the participants worked in managerial/supervisory jobs $(50.9 \%)$, while the remaining had professional/technical jobs (49.2\%). Slightly one-third of them worked in the education sector (37.2\%) and the remaining worked in various industries. On average, the participants were 35 years old and had been working with the current employer for five years. On average, foreigners had been working in Oman for eight years and outside their own country for 12 years. An overwhelming majority of non-Omanis $(95.6 \%)$ were self-initiated expatriates, while the small number was sent to work in Oman by their parent company.

\section{Measures}

\section{Knowledge sharing behaviour}

As mentioned earlier, two central behaviours of knowledge sharing, following De Vries et al. (2006), were identified: (a) knowledge donating, communicating one's personal intellectual capital to others; and (b) knowledge collecting, consulting others to get them to share their intellectual capital. The instrument developed by De Vries et al. (2006) was used to measure the two dimensions. Each dimension was measured by four items on a five-point Likert scale, ranging from ' 1 ' "strongly disagree" to '5' "strongly agree." A sample item of knowledge donating is, "I share information I have with my colleagues" while a sample item of knowledge collecting is, "I like to be informed of what my colleagues know." In their studies, the reliability coefficient of donating was 0.84 and of collecting was 0.75 .

\section{Perceived job security}

Job Insecurity Scale (JIS) with four items developed by De Witte (2000) was employed in this study. However, because we were concerned with job security rather than job insecurity, items that reflected job insecurity were reverse-scored on a five-point Likert scale, ranging from ' 1 ' "strongly disagree" to ' 5 ' "strongly agree." The instrument has been used and validated across countries and in different employment settings (De Cuyper et al., 2014).

\section{Perceived promotional opportunities}

We employed four items to measure perceived promotional opportunities, in which two items were adopted from Nelson, Basu, and Purdie (1998), which were found 
to have a reported reliability of 0.73 (Sommer \& Kulkani, 2012) and additional two from Lichtenstein and Alexander (2000). On a five-point Likert scale, ranging from ' 1 ' "strongly disagree" to '5' "strongly agree," participants were asked to indicate their degree of agreement or disagreement on items like "There are insufficient opportunities for advancement in this organisation (R)" and "I do not have the opportunity to develop myself for the future (R)."

\section{Perceived employability}

Four items developed by De Witte (1992, as cited in De Cuyper et al., 2014) were used to measure perceived employability. All items were measured on a five-point Likert scale, ranging from ' 1 ' "strongly disagree" to '5' "strongly agree." A sample item was "I am confident that I could quickly get another job". The instrument was chosen because it has been used earlier in a large European project among workers from different sectors and has been employed successfully also in other studies (e.g., De Cuyper, Van der Heijden, \& De Witte, 2011; De Cuyper et al., 2014). The four-item measure was reported to show a high reliability coefficient of 0.85 in De Cuyper et al.'s (2014) study.

\section{Demographic variables}

Table 1 shows the personal information we sought from the participants. In addition, we also asked non-Omani participants their passport nationality, how long have they been working in Oman, how long they have been working outside their country of residence, and whether they initiated their expatriation or sent by their parent company.

\section{RESULT}

The mean, standard deviations, correlations, and reliability coefficients of the instruments used are shown in Table 2. As shown, employability and security had a positive and significant relationship with knowledge donating and collecting. No significant correlation was found between perceived promotional opportunities and knowledge donating nor knowledge collecting.

In addition to the Pearson correlation analysis, we wanted to know which careerrelated practices were the strongest predictor of knowledge sharing and donating. Two regression models were built, each on different knowledge dimension. 
We found that the first model of knowledge donating was not significant $(\mathrm{F}=2.32, \mathrm{df}=3, \mathrm{p}=0.79)$. However, the second model of knowledge collecting was significant. Table 3 shows that the three career-related factors explained significantly close to 10 percent of the variance in knowledge collecting $(\mathrm{F}=4.31$, $\mathrm{df}=3, \mathrm{p}=0.01)$. The small variance explained suggests that other factors not considered in the present study influence knowledge collecting behaviour. This finding presents an opportunity for future research to carry out more studies on the factors that affect knowledge collecting behaviour.

Table 2

Mean, Standard Deviation, Inter-Correlations and Reliability Coefficients of Variables

\begin{tabular}{lccccc}
\hline & 1 & 2 & 3 & 4 & 5 \\
\hline Donating & $(0.80)$ & & & & \\
Collecting & $.56^{* *}$ & $(0.67)$ & & & \\
Employability & $.17^{*}$ & $.16^{*}$ & $(0.89)$ & & \\
Promotion & .07 & -.07 & $.19^{*}$ & $(0.84)$ & \\
Security & $.17^{*}$ & $.20^{*}$ & .09 & $.30^{* *}$ & $(0.72)$ \\
Mean & 3.97 & 3.95 & 3.63 & 3.32 & 3.95 \\
Standard deviation & 0.72 & 0.60 & 0.84 & 0.93 & 0.71 \\
\hline
\end{tabular}

Note:

** Significant at 0.001 (one-tailed test).

* Significant at 0.05 (one-tailed test).

Reliability coefficients are shown in the parentheses.

Table 3 also shows that each career-related practice predicted significantly knowledge collecting behaviour (using the cut-off point of 0.05 significance level), but only promotion opportunities had a negative relationship with knowledge collecting behaviour. This suggests that as promotion opportunities are perceived to be more available in the organisation, the less likely employees engage in knowledge collecting behaviour. However, employability and security had positive relationships with knowledge collecting behaviour, suggesting that the more employable and the more secure the job is perceived to be, the more likely employees will learn from their peers at work. In this regard, the finding provides empirical support for $\mathrm{H} 1$ and $\mathrm{H} 3$ but not $\mathrm{H} 2$. 
Faridahwati Mohd. Shamsudin et al.

Table 3

Regression Analyses on Knowledge Collecting

\begin{tabular}{|c|c|c|c|c|c|}
\hline & \multicolumn{2}{|c|}{ Unstandardised coefficients } & \multirow{2}{*}{$\frac{\text { Standardised coefficients }}{\text { Beta }}$} & \multirow{2}{*}{$\mathrm{t}$} & \multirow{2}{*}{ Sig. } \\
\hline & B & Std. Error & & & \\
\hline (Constant) & 3.03 & 0.36 & & 8.49 & 0.00 \\
\hline Employability & 0.13 & 0.06 & 0.19 & 2.16 & 0.03 \\
\hline Promotion & -0.11 & 0.06 & -0.18 & -1.94 & 0.05 \\
\hline Security & 0.20 & 0.08 & 0.24 & 2.69 & 0.01 \\
\hline $\mathrm{F}$ & $4.31 *$ & & & & \\
\hline $\mathrm{R}$ & 0.31 & & & & \\
\hline $\mathrm{R}^{2}$ & 0.09 & & & & \\
\hline Adjusted $\mathrm{R}^{2}$ & 0.07 & & & & \\
\hline
\end{tabular}

Note: * Significant at 0.01

Of the three career-related practices, Table 3 indicates that job security played the strongest predictor of knowledge collecting behaviour.

\section{DISCUSSION}

The present study was conducted to examine the influence of career-related factors on knowledge sharing behaviour from the social exchange lens. Interesting results emerge from the data collected among employees working in managerial and professional jobs across diverse organisations in Muscat, Oman. Contrary to our expectation, we found empirical support for the role of perceived job security, perceived employability, and perceived promotional opportunities in knowledge collecting behaviour but not in knowledge donating behaviour. Secondly, we found empirical evidence on the positive role of employability and security in predicting knowledge collecting behaviour, thus supporting our hypotheses. On the other hand, perceived promotional opportunities showed a negative influence on knowledge collecting behaviour, contrary to our prediction.

One of the unexpected results we found is that the model of knowledge donating behaviour was not empirically supported, prompting us to conclude that knowledge sharing behaviour in our sample refers to knowledge collecting behaviour. That is, when employees in our sample share knowledge they engage in learning from others and not in teaching others. If the situation is valid, it is difficult to speculate why this is so. However, trust may be a factor that hinders knowledge donating especially when parties to the sharing activities differ in national cultures (Chin, Yee, \& Geok, 2014). In Oman where Omanisation is vigorously pursued, such 
national project inadvertently may cause uneasiness and anxiety among guest workers as the country attempts to reduce their number and replace them with the local Omanis. Studies indicate that work environment characterized by a lack of autonomy and heightened control are likely to diminish trust (Holland, Cooper, \& Hecker, 2015; Laschinger, Shamian, \& Thomson, 2001). Trust deficit has been found to have a negative effect on work performance (Colquitt, Scott, \& LePine, 2007). Using this body of literature, it is, therefore, plausible to suggest that trust may be a likely factor that explains the absence of knowledge donating behaviour. Indeed, Mooradian et al. (2006) found a significant and positive relationship between interpersonal trust and knowledge sharing in a team. However, we recommend that future studies be conducted on the role of localisation policies in affecting workplace trust.

The positive influence of perceived job security and perceived employability is consistent with previous findings that such practices enhance knowledge sharing behaviour, in particular, the collecting dimension (Chiang et al., 2011; Fong et al., 2011). Job security reduces the feeling of anxiety and stress at work. When employees feel that their job is stable, the feeling of being at ease is likely to encourage them to learn new things at work. Studies have found that reduced stress is associated with positive work behaviour and well-being (Wickramasinghe, 2010; Yang et al., 2008). The higher the perceived employability, the more likely employees will learn from others to further enrich their capital reservoir. Consistent with social exchange theory, employees learn from their peers and other individuals as a way to return the "favor" made by the organisation in facilitating their career development. One of the ways to return the "favor" is by demonstrating positive work behaviour, such as learning from others. Learning from others is a type of behaviour expected from the organisation because by doing so the employees will be able to perform their work better, which collectively will lead to enhanced organisational effectiveness (Cabrera \& Cabrera, 2005; Wang \& Noe, 2010). Researchers have shown that team learning behaviour enhances the creativity of a team (Hirst, Van Knippenberg, \& Zhou, 2009).

Another unexpected result is the negative role perceived promotional opportunities have on knowledge collecting behaviour. This result suggests that the more promotional opportunities are available, the less likely the employees will learn from other individuals in the organisation. One of the plausible explanations for this finding may be that the promotion system implemented in the organisations is not merit-based but rather seniority-based or based on "who you know" or wasta (Swailes \& A1 Fahdi, 2010), consistent with the collectivist nature of the society that places emphasis on relationships (Reichel, Mayrhofer, \& Chudzikowski, 2009). In the Middle Eastern countries including Oman, though largely unaccepted, wasta is 
being practiced in many spheres of life including employment (Tlaiss \& Kauser, 2011). If indeed the promotion system is either largely seniority-based or is infiltrated by wasta elements, then such system may provide a disincentive for the employees to engage in learning behaviour. More research is needed to establish such plausible explanation.

\section{Practical Implications}

How are the findings useful to managers and practitioners? To encourage employees to learn from their peers and other individuals, managers needs to examine their current career-related practices particularly the provision of job security and employability. Providing job security may not necessarily be an option for the organisation especially to guest workers who generally have a contractual employment. In light of this, providing another support that helps the employees to be employable is a viable option the organisation can pursue. But, for the local nationals, offering job security can be an effective tool to motivate them to share their knowledge across the organisation. As Oman, like any other countries in the Middle East, faces a somewhat high unemployment especially among its graduates (De Bel-Air, 2015), providing a secure job may motivate them to engage in knowledge sharing behaviour. However, to do this, knowledge management activities that relate to learning, sharing, and application of knowledge can be integrated with policies on job security. Such measure can also be applied when it comes to enhancing the employability of the employees. The organisation can stipulate that the employees share and apply their knowledge with others every time they have completed their training or development programs. In this way, when they decide to leave the organisation voluntarily, relevant knowledge is not lost.

If indeed the promotion system is based on seniority or influenced by wasta, then the organisation has to re-visit such practice as it does not encourage the employees to engage in knowledge collecting behaviour. We speculate that when the promotion system is merit-based that the employees will have the incentive to learn from others because gaining more knowledge allows them to be more competitive.

\section{Limitations}

While the findings may have some merit, they need to be interpreted by taking into consideration the limitations the present study has. Firstly, because the correlational nature, causal relations are difficult to ascertain. Though we have 
framed our understanding from the social exchange perspective, it is possible that knowledge sharing behaviour affects whether or not the employees' opportunities to secure their job and promotion. To determine this, different research design needs to be considered. Secondly, common method variance (CMV), i.e. variance attributable to the measurement method rather than to the constructs the measures represent (Podsakoff, MacKenzie, Lee, \& Podsakoff, 2003) may also pose a threat to the present study. Although we attempted to address this bias administratively by designing the questionnaire in which the participants were guaranteed anonymity and confidentiality, assuring that there were no right or wrong answers, and encouraging them to answer the questions as honestly as possible. We also ensured that ambiguity and vagueness to the items were minimized by pre-testing the questionnaire first, following the recommendation of Chang, van Witteloostuijn, and Eden (2010), we acknowledge that such threat cannot be eliminated entirely. Thirdly, the finding may also not generalisable to a much wider population of employees of different backgrounds.

\section{Conclusion and Future Research Directions}

Knowledge sharing research will continue to grow, reflecting the significance of knowledge as an important resource to the organisation in developing its competitive advantage. While our research has managed to fill the gaps in the literature, more research needs to be conducted in this area. Firstly, we recommend that this study is replicated in different contexts, such as Malaysia, which is also hosting foreign workers (both skilled and non-skilled). Engaging in such study will help us develop relevant theories of knowledge sharing. Secondly, the variance explained offers opportunities to investigate other factors that influence knowledge sharing. Studying the topic at the individual and group levels is a possibility. Thirdly, as knowledge sharing does not occur in a vacuum but its occurrence may be conditioned by some factors, examining possible moderators that further promote or inhibit it needs to be carried out.

\section{REFERENCES}

Ardichvili, A., Page, V., \& Wentling, T. (2003). Motivation and barriers to participation in virtual knowledge-sharing communities of practice. Journal of Knowledge Management, 7(1), 64-77. http://dx.doi.org/10.1108/13673270310463626

Auh, S., \& Menguc, B. (2013). Knowledge sharing behaviors of industrial salespeople: An integration of economic, social psychological, and sociological perspectives. European Journal of Marketing, 47(8), 1333-1355. doi: 10.1108/ 03090561311324354 
Bartol, K. M., \& Srivastava, A. (2002). Encouraging knowledge sharing: The role of organizational rewards systems. Journal of Leadership and Organization Studies, 9(1), 64-76. http://dx.doi.org/10.1177/107179190200900105

Berntson, E., \& Marklund, S. (2007). The relationship between perceived employability and subsequent health. Work \& Stress, 21(3), 279-292. http://dx.doi. org/10.1080/02678370701659215

Blau, P. M. (1964). Exchange and power in social life. New York: John Wiley.

Bock, G. W., Zmud, R. W., Kim, Y. G., \& Lee, J. N. (2005). Behavioral intention formation in knowledge sharing: Examining the roles of extrinsic motivators, socialpsychological forces, and organizational climate. MIS Quarterly, 29(1), 87-111.

Briscoe, J. P., \& Hall, D. T. (2006). The interplay of boundaryless and protean careers: Combinations and implications. Journal of Vocational Behavior, 69, 4-18. http:// dx.doi.org/10.1016/j.jvb.2005.09.002

Cabrera, E. F., \& Cabrera, A. (2005). Fostering knowledge sharing through people management practices. International Journal of Human Resource Management, 16, 720-735. http://dx.doi.org/10.1080/09585190500083020

Cabrera, A., Collins, W. C., \& Salgado, J. F. (2006). Determinants of individual engagement in knowledge sharing, The International Journal of Human Resource Management, 17(2), 245 - 264. doi: 10.1080/09585190500404614

Chang, S-J., van Witteloostuijn, A., \& Eden, L. (2010). From the editors: Common method variance in international business research. Journal of International Business Studies, 41, 148-184. doi: 10.1057/jibs.2009.88

Chay, Y.-W., \& Aryee, S. (1999). Potential moderating influence of career growth opportunities on careerist orientation and work attitudes: Evidence of the protean career era in Singapore. Journal of Organizational Behavior, 20(5), 613-623. http://dx.doi.org/10.1002/(SICI)1099-1379(199909)20:5<613::AIDJOB979>3.0.CO;2-A

Chin, W. C., Yee, Y. Y., \& Geok, C. G. (2014). Knowledge sharing of academic staff. Library Review, 63(3), 203-223. http://dx.doi.org/10.1108/LR-08-2013-0109

Chiang, H.-H., Han, T.-S., \& Chuang, J.-S. (2011). The relationship between highcommitment HRM and knowledge-sharing behavior and its mediators. International Journal of Manpower, 32(5/6), 604-622. http://dx.doi. org/10.1108/01437721111158224

Chen, T. Y., Chang, P. L., \& Yeh, C. W. (2004). A study of career needs, career development programs, job satisfaction and the turnover intentions of R\&D personnel. Career Development International, 9(4), 424-4437. http://dx.doi. org/10.1108/13620430410544364

Colquitt, J. A., Scott, B. A., \& LePine, J. A. (2007). Trust, trustworthiness, and trust propensity: a meta-analytic test of their unique relationships with risk taking and job performance. Journal of Applied Psychology, 92(4), 909-927. http://dx.doi. org/10.1037/0021-9010.92.4.909

De Bel-Air, F. (2015). Demography, migration, and the labor market in Oman. GLMM - EN - No. 9/2015, Migration Policy Centre: European University Institute. Retrieved on December 12, 2015 from http:/gulfmigration.eu/media/pubs/exno/ GLMM_EN_2015_09.pdf 
De Cuyper, N., Baillien, E., \& De Witte, H. (2009). Job insecurity and workplace bullying among targets and perpetrators: Moderation by employability. Work \& Stress, 23, 206-224. http://dx.doi.org/10.1080/02678370903257578

De Cuyper, N., Schreurs, B., Elst, T. V., Baillien, E., \& De Witte, H. (2014). Exemplification and perceived job insecurity: Associations with self-rated performance and emotional exhaustion. Journal of Personnel Psychology, 13(1), 1-10. http://dx.doi.org/10.1027/1866-5888/a000099

De Cuyper, N., Van der Heijden, B. I. J. M., \& De Witte, H. (2011). Associations between perceived employability, employeewell-being, andits contribution to organizational success: A matter of psychological contracts? The International Journal of Human Resource Management, 22, 1486-1503. doi: 10.1080/09585192.2011.561962

De Vries, R. E., Van den Hooff, B., \& De Ridder, J. A. (2006). Explaining knowledge sharing: the role of team communication styles, job satisfaction, and performance beliefs. Communication Research, 33, 115-135. doi: 10.1177/0093650205285366

De Witte, H. (2000), Work ethics and job insecurity: Measurement and consequences for well-being, satisfaction and performance. In Bouwen, R., De Witte, K., De Witte, H. and Taillieu, T. (Eds), From group to community (pp. 325-350). Leuven: Garant [in Dutch].

De Witte, H., \& Näswall, K. (2003). 'Objective' vs 'subjective' job insecurity: Consequences of temporary work for job satisfaction and organizational commitment in four European countries. Economic and Industrial Democracy, 24, 149-188. http://dx.doi.org/10.1177/0143831X03024002002

Deckop, J. R., Cirka, C. C., \& Andersson, L. M. (2003). Doing unto others: The reciprocity of helping behavior in organizations. Journal of Business Ethics, 47(2), 101-113. http://dx.doi.org/10.1177/0143831X03024002002

Dessler, G. (1991). Human resource management ( $5^{\text {th }}$ ed.). New Jersey: Prentice Hall.

Eby, L. T., Allen, T. D., \& Brinley, A. (2005). A cross-level investigation of the relationship between career management practices and career-related attitudes. Group \& Organization Management, 30(6), 565-596. http://dx.doi. org/10.1177/1059601104269118

Ellickson, M. C. (2002). Determinants of job satisfaction of municipal government employees. Public Personnel Management, 31(3), 343-358. http://dx.doi. org/10.1177/009102600203100307

Fong, C.-Y., Ooi, K.-B., Tan, B.-I., Lee, V.-H., \& Chong, A. Y.-L. (2011). HRM practices and knowledge sharing: An empirical study. International Journal of Manpower, 32(5/6), 704-723. http://dx.doi.org/10.1108/01437721111158288

Foong-ming, T. (2008). Linking career development practices to turnover intention: The mediator of perceived organizational support. Journal of Business and Public Affairs, 2(1), 1-16.

Gagné, M. (2009). A model of knowledge-sharing motivation. Human Resource Management, 48(4), 571-589. http://dx.doi.org/10.1002/hrm.20298

Gouldner, A. W. (1960). The norm of reciprocity: A preliminary statement. American Sociological Review, 25, 161-178. http://dx.doi.org/10.2307/2092623 
Hall, D. T., \& Moss, J. E. (1998). The new protean career contract: Helping organizations and employees adapt. Organizational Dynamics, Winter, 22-37. http://dx.doi. org/10.1016/S0090-2616(98)90012-2

Hall, D. T., \& Moss, J. E. (1999). The new protean career contract: Helping organizations and employees adapt. Organizational Dynamics, 26(3), 22-37. http://dx.doi. org/10.1016/S0090-2616(98)90012-2

Hirst, G., Van Knippenberg, D., \& Zhou, J. (2009). A cross-level perspective on employee creativity: Goal orientation, team learning behavior, and individual creativity. Academy of Management Journal, 52(2), 280-293. http://dx.doi.org/10.5465/ AMJ.2009.37308035

Holland, P. J., Cooper, B., \& Hecker, R. (2015). Electronic monitoring and surveillance in the workplace: The effects on trust in management, and the moderating role of occupational type. Personnel Review, 44(1), 161-175. http://dx.doi.org/10.1108/ PR-11-2013-0211

International Labor Organization (ILO). (2010). Decent Work Country Programme 2010-2013. Retrieved on December 12, 2015 from http://www.ilo.org/public/ english/bureau/program/dwcp/download/oman.pdf

Iqbal, A. (2010). Employee turnover: Causes, consequences and retention strategies in the Saudi organizations. The Business Review, Cambridge, 16(2), 275-281.

Ismail Al-Alawi, A., Yousif Al-Marzooqi, N., \& Fraidoon Mohammed, Y. (2007). Organizational culture and knowledge sharing: Critical success factors. Journal of Knowledge Management, 11(2), 22-42. http://dx.doi.org/10.1108/ 13673270710738898

Jer Yuen, T., \& Shaheen Majid, M. (2007). Knowledge-sharing patterns of undergraduate students in Singapore. Library Review, 56(6), 485-494. http://dx.doi.org/ $10.1108 / 00242530710760382$

Kim, S. (2002). Organizational support of career development and job satisfaction: A case study of the Nevada operations office of the department of energy. Review of Public Personnel Administration, 22(4), 276-294. http://dx.doi. org/10.1177/073437102237813

Kraimer, M. L., Wayne, S. J., Liden, R. C., \& Sparrowe, R. T. (2005). The role of job security in understanding the relationship between employees' perceptions of temporary workers and employees' performance. Journal of Applied Psychology, 90, 389-398. http://dx.doi.org/10.1037/0021-9010.90.2.389

Kulkarni, U. R., Ravindran, S., \& Freeze, R. (2006). A knowledge management success model: Theoretical development and empirical validation. Journal of Management Information Systems, 23(3), 309-347. http://dx.doi.org/10.2753/ MIS0742-1222230311

Laschinger, H. K. S., Purdy, N., Cho, J., \& Almost, J. (2006). Antecedents and consequences of nurse managers' perceptions of organizational support. Nursing Economics, 24(1), 20-29.

Laschinger, H. K. S., Shamian, J., \& Thomson, D. (2001). Impact of magnet hospital characteristics on nurses' perceptions of trust, burnout, quality of care, and work satisfaction. Nursing Economics, 19(5), 209-219. 
Lawler, E. E., \& Suttle, J. L. (1973). Expectancy theory and job behavior. Organizational Behavior and Human Performance, 9(3), 482-503. http://dx.doi.org/10.1016/ 0030-5073(73)90066-4

Lichtenstein, R., \& Alexander, J. A. (2000). Perceived promotional opportunities in veteran affairs hospitals. The Journal of Applied Behavioral Science, 36(3), 269-296. http://dx.doi.org/10.1177/0021886300363001

Maceda, C. (2014, May 2). UAE firms to see more job hoppers: Increased job opportunities, demand for higher salaries to trigger more attritions. GulfNews [online newspaper]. Retrieved on April 25, 2015 at: http:/gulfnews.com/business/sectors/careers/uaefirms-to-see-more-job-hoppers-1.1327195

Maslow, A. (1943). A theory of human motivation. Psychological Review, 50(4), 370-396. http://dx.doi.org/10.1037/h0054346

Matanle, P. (2006). Beyond lifetime employment? Re-fabricating Japan's employment culture. Perspectives on Work, Employment and Society in Japan, 58-78.

Matzler, K., Renzl, B., Müller, J., Herting, S., \& Mooradian, T. A. (2008). Personality traits and knowledge sharing. Journal of Economic Psychology, 29(3), 301-313. http://dx.doi.org/10.1016/j.joep.2007.06.004

Matzler, K., Renzl, B., Mooradian, T., von Krogh, G., \& Mueller, J. (2011). Personality traits, affective commitment, documentation of knowledge, and knowledge sharing. The International Journal of Human Resource Management, 22(02), 296-310. http://dx.doi.org/10.1080/09585192.2011.540156

Mooradian, T., Renzl, B., \& Matzler, K. (2006). Who trusts? Personality, trust and knowledge sharing. Management Learning, 37(4), 523-540. http://dx.doi. org/10.1177/1350507606073424

Nelson, D., Basu, R., \& Purdie, R. (1998). An examination of exchange quality and work stressrs in leader-follower dyads. International Journal of Stress Management, 5 , 103-112. http://dx.doi.org/10.1023/A:1022907831243

Podsakoff, P. M., MacKenzie, S. B., Lee, J.-Y., \& Podsakoff, N. P. (2003). Common method biases in behavioral research: A critical review of the literature and recommended remedies. Journal of Applied Psychology, 88, 879-903. doi: 10.1037/00219010.88.5.879

Reichel, A., Mayrhofer, W., \& Chudzikowski, K. (2009). Human resource development in Austria: A cultural perspective of management development. In C. D. Hansen \& Y.-t. Lee (Eds.), The cultural contexts of human resource development (pp. 90-107). Hampshire: Palgrave Macmillan. http://dx.doi.org/10.1057/ 97802302366606

Robbins, S., Judge, T. A., Millett, B., \& Boyle, M. (2013). Organizational behavior. Upper Saddle River, NJ: Pearson.

Silla, I., Gracia, F. J., \& Peiro, J. M. (2005). Job insecurity and health-related outcomes among different types of temporary workers. Economic and Industrial Democracy, 26(1), 89-117. doi: 10.1177/0143831X05049404

Schappe, S. P. (1998). The influence of job satisfaction, organizational commitment, and fairness perceptions on organizational citizenship behavior. The Journal of Psychology, 132(3), 277-290. http://dx.doi.org/10.1080/00223989809599167 
Sommer, K. L., \& Kulkani, M. (2012). Does constructive performance feedback improve citizenship intentions and job satisfaction? The roles of perceived opportunities for advancement, respect, and mood. Human Resource Development Quarterly, 23(2), 177-201. http://dx.doi.org/10.1002/hrdq.21132

Stahl, G. K., Chua, C. H., Acliguiri, P., Cerdin, J-L., \& Taniguchi, M. (2009). Predictors of turnover intentions in learning-driven and demand-driven international assignments: The role of repatriation concerns, satisfaction with company support, and perceived career advancement opportunities. Human Resource Management, 48(1), 89-109. http://dx.doi.org/10.1002/hrm.20268

Sturges, J., Guest, D., Conway, N., \& Mackenzie Davey, K. (2002). A longitudinal study of the relationship between career management and organizational commitment among graduates in the first ten years at work. Journal of Organizational Behavior, 23, 731-748. http://dx.doi.org/10.1002/job.164

Sverke, M., Hellgren, J., \& Naswall, K. (2002). No security: A meta-analysis and review of job insecurity and its consequences. Journal of Occupational Health Psychology, 7, 242-264. http://dx.doi.org/10.1037/1076-8998.7.3.242

Swailes, S., \& Al Fahdi, S. (2010). Voluntary labor turnover in the Omani public sector. Research Memorandum \#87. University of Hull: Centre for Management and Organizational Learning. Retrieved from http://www2.hull.ac.uk/hubs/pdf/ Memorandum $\% 2087 \% 20$ Swailes.pdf

Tlaiss, H., \& Kauser, S. (2011). The importance of wasta in the career success of Middle Eastern managers. Journal of European Industrial Training, 35(5), 467-486. http://dx.doi.org/10.1108/03090591111138026

UAE firms grapple with high staff turnover cost. (2008). Gulf News [online newspaper]. Retrieved on December 11, 2015 from http:/gulfnews.com/business/sectors/ general/uae-firms-grapple-with-high-staff-turnover-cost-1.149010

Van Den Hooff, B., \& van Weenen, F. D. L. (2004). Committed to share: commitment and $\mathrm{CMC}$ use as antecedents of knowledge sharing. Knowledge and Process Management, 11(1), 13-24. http://dx.doi.org/10.1002/kpm.187

Wang, W.-T., \& Houe, Y. (2015). Motivations of employees' knowledge sharing behaviors: A self-determination perspective. Information and Organization, 25, 1-26. http://dx.doi.org/10.1016/j.infoandorg.2014.11.001

Wang, S., \& Noe, R. A. (2010). Knowledge sharing: A review and directions for future research. Human Resource Management Review, 20(2), 115-131. http://dx.doi. org/10.1016/j.hrmr.2009.10.001

Whitener, E. M. (2001). Do 'high commitment' human resource practices affect employee commitment? A cross-level analysis using hierarchical linear modeling. Journal of Management, 27, 515-535. http://dx.doi.org/10.1177/014920630102700502

Wickramasinghe, V. (2010). Work-related dimensions and job stress: The moderating effect of coping strategies. Stress and Health, 26, 417-429. http://dx.doi.org/10.1002/ smi. 1314

Willman, P., O'Creevy, M. F., Nicholson, N., \& Soane, E. (2001). Knowing the risks: Theory and practice in financial market trading. Human Relations, 54(7), 887910. http://dx.doi.org/10.1177/0018726701547005 
Wu, W. -L. (2013). To share knowledge or not: Dependence on knowledge-sharing satisfaction. Social Behavior and Personality: An International Journal, 41(1), 47-58. http://dx.doi.org/10.2224/sbp.2013.41.1.47

Wyatt, J. C. (2001). Management of explicit and tacit knowledge. Journal of the Royal Society of Medicine, 94(1), 6-9.

Yang, L-Q., Che, H., \& Spector, P. E. (2008). Job stress and well-being: An examination from the view of person-environment fit. Journal of Occupational and Organizational Psychology, 81, 567-587. http://dx.doi.org/10.1348/096317907X243324

Yao, L. J., Kam, T. H. Y., \& Chan, S. H. (2007). Knowledge sharing in Asian public administration sector: The case of Hong Kong. Journal of Enterprise Information Management, 20(1), 51-69. http://dx.doi.org/10.1108/17410390710717138

Yousaf, A., \& Sanders, K. (2012). The role of job satisfaction and self-efficacy as mediating mechanisms in the employability and affective organizational commitment relationship: A case from a Pakistani university. Thunderbird International Business Review, 54(6), 907-919. http://doi.org/10.1002/tie.21511

Zapf, D., \& Einarsen, S. (2001). Bullying in the workplace: Recent trends in research and practice-an introduction. European Journal of Work and Organizational Psychology, 10(4), 369-373. http://dx.doi.org/10.1080/13594320143000807 
